\title{
Solving Livestock Production Problems Through Ideas, Creativity, Innovation and Commercialization (ICIC) Ways in the Tropics
}

\author{
DAHLAN, I.
}

Professor of Animal Production Systems, Department of Animal Science, Faculty of Agriculture, Universiti Putra Malaysia 43400 Serdang, Selangor, Malaysia

How to cite this paper: DAHLAN, I. (2019) Solving Livestock Production Problems Through Ideas, Creativity, Innovation and Commercialization (ICIC) Ways in the Tropics. International Journal of Food Science and Agriculture, 3(4), 308-315.

DOI: 10.26855/ijfsa.2019.12.007

*Corresponding author: DAHLAN, I., Professor of Animal Production Systems, Department of Animal Science, Faculty of Agriculture, Universiti Putra Malaysia 43400 Serdang, Selangor, Malaysia.

Email: dahlandpp55@gmail.com

\begin{abstract}
This paper attempts to apply system thinking in solving livestock production and food security problems especially in tropical countries. System thinking is synonymous with ICIC ways which means Idea, Creativity, Innovation, and Commercialization. Through ICIC ways agriculture production systems can be efficiently managed and sustainable. In order to solve food security problems we need to consider 3Ps (people, planet and profit) aspect of development. Three examples will be used to explain ICIC approach are Livestock-crop plantation (LICRO) integrated production systems as a future livestock production system in the tropics, Oil palm fronds (OPF) as a fiber source for herbivores feeding and Dehydrated-processed food waste (DFW) as an ingredient in poultry feed formulation for free range poultry production system. This paper will apply system approach to solve some of livestock production problems such as limited grazing land space for ruminant (cattle, buffalo, goat, sheep and deer), utilizing readily available green fiber source (waste) such as OPF as herbivore feedstuff and re-utilize food waste (processed and dehydrated) from restaurants, hospital canteens, hotels and others as replacement for expensive imported feed grains in poultry feeding management. Food security problems in term of low in self-sufficiency level in animal protein food such as meat and milk from ruminants and egg \& poultry meat can be solved efficiently and economically through application of appropriate technology and innovations. All problems can be turned into opportunities through ICIC ways; not only solving primary problem of resource scarcity but also contributes towards multiple output and commercialization of animal protein food items and animal products from the system.
\end{abstract}

\section{Keywords}

Food security; System thinking; Idea; Creativity; Innovation; Commercialization; Integrated livestock-crop plantation system; Oil palm frond fiber feed; Dehydrated food waste as feed

\section{Introduction}

There is an obvious need to boost food and livestock production in the tropics; firstly - because an enormous expenditure is entailed in importing food and feedstuffs especially grains for human and animal. Secondly - because of the demand for food commodities (including livestock products and feedstuffs) will be expected to grow at a rate commensurate with that of the population. In order to ensure food security, food and farming policy of the country should be sustainably managed (Lang and Heasman, 2004). Currently, animal production must increasingly compete with other forms of production for resources, especially energy (feed sources), but also for land, water, finance and labour (Dahlan, 2009; Jackson et al., 1982). This creates a greater need to develop systems which maximize efficiency 
(Dahlan, 2000; Baker, 2006). Sustainable animal production; Must be environmentally beneficial, ethically defensible, socially acceptable and relevant to the particular aims, needs and resources of the community they are designed to serve (Gallopin and Raskin, 2002). They should also be sustainable with the dynamic changes of the agricultural systems (Spedding, 1996; Dahlan, 2002).

Objectives of this paper are to explore the sustainability of animal-agricultural production systems in the tropics in relation to the availability of resources, system of farming or production and marketing systems and to evaluate recent development in animal-agricultural production in Malaysia through system approach or idea, creativity, innovation and commercialization (ICIC) ways.

\section{ICIC ways}

System thinking process can be conceptualized as ICIC ways (Fig. 1). Food security problems can be solved through getting ideas (I) by using SWOT analysis - strength (have factors), weakness (do not have factors), opportunity (will have factors) and threats (constraints or will not have factors). Followed by creativity (C) through finding new or alternative ways and innovation (I) through development of appropriate technology and invention. These processes will be more meaningful and worth through commercialization $(\mathrm{C})$ of research output or products.

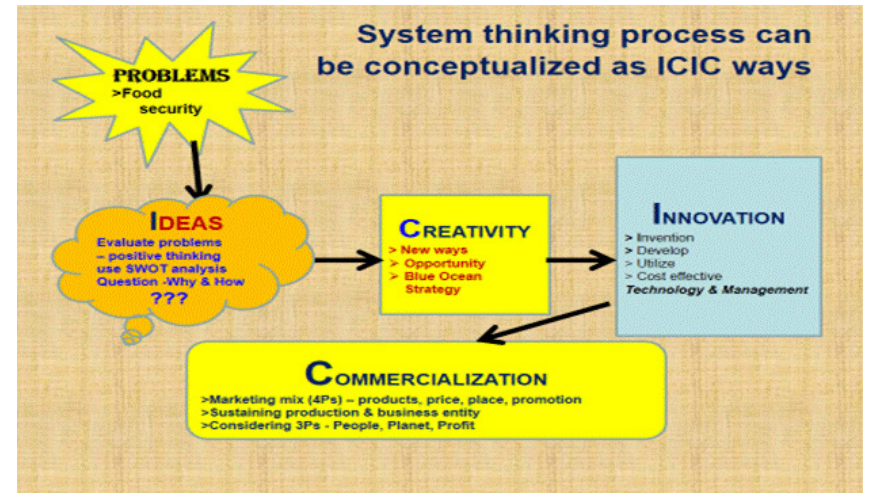

Fig. 1. Conceptual model of solving food security problems through ICIC ways ${ }^{\circ}$.

\section{Contributions of animal-agriculture}

Animals provide protein foods - a complete food (meat, milk, egg) for human diet. Animal protein contains most of the essential nutrients for the human dietary requirements in term of amino acids, fatty acids, minerals, vitamins and energy. Animals also provide items of pharmaceuticals, biological (hormones, antibodies, vaccine, enzymes, etc), cosmetic and mineral supplements (Dicalcium phosphate-DCP, Fe, Na, etc). These products are essential for human nutrition especially for growth, health maintenance and normal body function. Other contributions; Draught power for ploughing, pulling cart, transportation e.g. pulling oil palm fresh fruit bunch in plantation using buffalo, equipment, tools and clothing- bone tools, wool, leather, hide, skin, etc, Fertilizer - from faeces, urine and abattoir by-products and waste, Biological recycle machine - utilizing agricultural by-products fibrous material as feeds (ruminants and herbivores), Biological weeder - cattle, sheep, deer and others grazing weed in plantations, Recreations - main component in bio-parks and agro-tourism activity, pets, hobbies, sports, games and etc, Biological experimental animal - testing drugs (SPF animal), vaccine and diseases, development of vaccines and antibodies, and sentinel animal, and Bio-fuel - bio-gas (methane gas) from intensive livestock production systems.

Animal-agricultural industries also contribute towards national food security. This is accomplished in two ways;

- Provides adequate important food items for the country and

- Reduces the import of food items and forex outflow to other countries.

This diminishes country over-dependency on foreign producers.

Animal production has great opportunities in Malaysia and tropical countries, especially in the ruminant sector. Animalagriculture can be the core industry that can be linked to other important industries and act synergistically to effectuate more efficient dynamic production, manufacturing and service systems. The involvement of animal-agriculture in plantation sectors such as oil palm plantation can be in the form of integrating ruminants into the plantation and utilizing oil palm by-products as their feedstuff. Involvement in tourism industry will be in the form of halal (Islamic tourism - 
aqiqah \& qurban) and quality food service, animal recreations and provide a unique bio-parks and biological services (Dahlan et al., 1994). One of the most important contribution of animal-agricultural production is in providing halal quality products (food, pharmaceutical, cosmetics, biological, industrial biochemical, etc.) for the Muslims. Because of the high demand for halal and quality products especially in food industries, synergistic merging of related industries should be encouraged.

New approach in animal production and industries through venture into downstream processing such as processing of by-products for high value products will become more efficient and profitable industry. Hi-tech halal bio-materials such as Dicalcium phosphate from bone, collagen and gelatin from skin, suture catgut from esophagus and others will turn low value items into expensive products.

\section{Potential areas for future animal-agriculture in the tropics}

- Licro - Livestock-crops plantation integrated production systems (Dahlan Ismail, 1993; Dahlan and Kamal Hisyam, 2014).

>>Especially ruminants - oil palm, rubber \& agroforestry integrated production systems

- Utilization of agricultural by-products (ABP) (Dahlan, 2002; Dahlan, 2013) and food waste as animal feed \& bioindustries (Hussein and Dahlan 2015; Nadia et al., 2016; Aliyu Ahmed Yusuf, 2016; and Mohammed Farooq Abdulhameed Al-Qazzaz, 2019).

- Rearing livestock for other activities - multiple output concepts in production. >>Recreation, conservation and agro-tourism (Dahlan et al., 1994; Dahlan, 2009).

\section{Livestock-crops plantation integrated production systems solving agricultural land use problems}

Livestock-crops integrated production systems (LICRO) are complex agricultural systems that comprising many interacting components. Complex LICRO systems comprising components such as tree crops plantation systems, management systems, animal production systems, and others, cannot be successfully handled within the confines of a single discipline (Dahlan Ismail, 1993). A multidisciplinary approach is needed. If agriculturalists and decision makers ignore the ecological setting of integrated farming systems, the result will be harmful exploitation of the natural environment. Ecological concept can be easily incorporated into decisions about resource management in LICRO systems. Sustainable development approach should be followed in order to develop sustainable animal-agricultural industry in the plantation sectors (Dahlan, 2002; Campbell and Sayer, 2003).

New concepts need to be created, explored and introduced for agriculture to remain competitive with other industries in developing (tropical) countries. The new millennium approach for agricultural production systems in most of tropical or developing countries in the world must be based on an integrated approach (Dahlan, 2000; Campbell and Sayer, 2003). Efficiencies and economies will come by sharing land space, labour, management, professionals, products and byproducts utilizations, and infrastructures for production of multiple commodities and activities (multiple output concept). Grazing animals on land used simultaneously for crop production is commonly known as integrated or 'land-sharing' livestock-production system. Similar systems for the production of timber and food crops or animals on the same land unit are called 'agroforestry' (Dahlan, 2002; Dahlan and Dawend, 2013; Dahlan and Dawend 2015). This system offers great promise and has several advantages, such as improved fertility of the land via the return of dung and urine, control of waste herbage or weed growth and reduced use of herbicides, easier management of the crop and distinct possibilities of increased crop yields, the sale of animals and their products adds to the returns from the systems. In other words, this system offers more efficient resource utilization. Other advantages; The development of livestock through integration with plantation crops such as oil palm, rubber, coconut, and forest replantation such as acacia show particular promise (Dahlan and Kamal Hisyam, 2014; Dahlan, 2005). The system provides feeds such as the undergrowth or ground vegetation which forms part of the ecosystem of oil palm, rubber, coconut and acacia plantations, the most critical factor in ruminant production, may be made available at a much lower cost than the other conventional, monoculture animal production system or other extensive (open pastures) animal production systems (Awaludin, 2000). The canopy provides shade that reduces the heat stress problem facing animals in the tropics.

Mega scale ruminant production in the tropics can be developed through strong support from oil palm plantation sector as their corporate social responsibility (CSR) contribution for livestock farmers due to using agriculture land for plantation instead of grazing areas (Dahlan and Kamal Hisyam, 2014). Integrated production systems such as cattle and buffalo integrated farming (beef and dairy) can have sufficient feed materials and grazing space from the plantation areas. Buffalo can also contribute draught power in handling fresh fruits bunch (FFB) in plantations (Dahlan, 2013). 
Extra activities such as agro-tourism can be included in the production systems (Dahlan, 2009).

\section{Utilization of agricultural by-products (ABP) solving feed production problems}

Production of export crops lead to huge production of ABP. Local production of feeds for the livestock is small relative to the requirement. Livestock (non-ruminant) feed requirements are met largely by importing cereal grains, particularly corn. Ruminant animals - can use agricultural by-products from export crops (palm kernel cake, palm oil mill effluent, oil palm frond and palm press fiber from oil palm, pineapple waste and pineapple plant waste, cocoa pods and husk from cocoa and others) as feed resources. We are lucky enough to have plenty of agricultural by-products especially from the oil palm industry that can be utilized to substitute some of the imported feed ingredients for the livestock (Table 1). With new technologies, improvement of the nutritive quality of agricultural by-products can be developed for livestock feeding. Most ABP are fibrous type of material. These materials are suitable for feeding ruminants. In Malaysia the most abundance ABP are oil palm by-products (OPBP), cocoa, pineapple, coffee, and rice by-products. Other ABP or crop residues are available in small quantities and the production is seasonal.

Oil palm has numerous by-products that can be used as animal feed. Most of oil palm by-products (OPBP) are used in its fresh form or after processing it as ruminant feed. Two important OPBP are palm kernel cake or expeller (PKC/ PKE) and oil palm frond (OPF). Both OPBP can be used in almost all livestock species. By maximizing the utilization of OPBP as livestock feed, Malaysia can feed up to 5.0 million heads of cattle. Ruminants can utilize OPBP up to $90 \%$ as dry matter basis in the diets. Quality of livestock products can be improved through proper feeding and formulation of OPBP in the diets. The utilization of OPBP as livestock feed will thus present significant contributions to the development of livestock industry in Malaysia.

Table 1. Chemical composition of common ABPs for total mixed ration (TMR) ingredients.

\begin{tabular}{|c|c|c|c|c|c|c|c|c|c|c|}
\hline \multirow{2}{*}{$\mathbf{A B P} \mathbf{P}^{\mathbf{a}}$} & DM & $\mathbf{C P}$ & $\mathbf{E E}$ & $\mathbf{C F}$ & NDF & ADF & Ash & $\mathrm{Ca}$ & $\mathbf{P}$ & \multirow{2}{*}{$\begin{array}{c}\text { ME } \\
\text { MJ/kgDM }\end{array}$} \\
\hline & \multicolumn{9}{|c|}{$(\%)$} & \\
\hline \multicolumn{11}{|c|}{ Oil seed cake (concentrate group) } \\
\hline PKC(E) & 94.0 & 16.2 & 8.2 & 18.0 & 74.3 & 52.9 & 4.3 & 0.2 & 0.6 & 10.2 \\
\hline $\mathrm{PKC}(\mathrm{S})$ & 88.5 & 14.2 & 3.2 & 21.0 & 68.2 & 42.6 & 4.2 & 0.3 & 0.7 & 9.6 \\
\hline POME & 89.6 & 12.1 & 24.1 & 15.2 & 63.0 & 51.8 & 18.6 & 0.6 & 0.4 & 9.8 \\
\hline Copra cake & 89.8 & 20.9 & 8.0 & 12.0 & 72.2 & 36.3 & 5.2 & 0.2 & 0.6 & 10.2 \\
\hline \multicolumn{11}{|c|}{ Crop residues (fibrous group) } \\
\hline PPF & 94.5 & 4.3 & 21.0 & 36.4 & 84.5 & 69.3 & 9.0 & 0.3 & 0.1 & 4.2 \\
\hline OPF & 34.9 & 7.0 & 2.4 & 32.3 & 78.7 & 53.6 & 5.0 & 0.4 & 0.1 & 6.5 \\
\hline Coffee pulp & 90.8 & 10.0 & 2.2 & 29.7 & 36.8 & 27.6 & 8.8 & 0.2 & 0.6 & 8.1 \\
\hline Cocoa pod (D) & 86.0 & 7.1 & 0.9 & - & 74.7 & 36.0 & 4.7 & 0.3 & 0.5 & 6.4 \\
\hline Cocoa pod (F) & 18.7 & 7.2 & 1.1 & 31.5 & - & - & 16.4 & 0.5 & 0.7 & 7.8 \\
\hline Pineapple press & 14.8 & 7.1 & 1.2 & 25.5 & 45.0 & 20.8 & 4.5 & 0.3 & 0.2 & 9.5 \\
\hline Pineapple PW & 16.5 & 5.8 & 3.1 & 30.9 & 48.1 & 22.3 & 2.1 & 0.2 & 0.1 & 7.8 \\
\hline Rice straw & 88.7 & 4.2 & 1.2 & 30.4 & 72.5 & 43.2 & 18.4 & 0.5 & 0.3 & 6.2 \\
\hline Sago pith & 89.3 & 3.1 & 0.6 & 6.3 & 23.3 & 10.1 & 4.5 & 0.1 & 0.1 & 10.3 \\
\hline Plantain peels & 16.3 & 7.6 & 1.5 & - & 47.2 & 28.6 & 5.7 & 0.4 & 0.6 & 12.8 \\
\hline
\end{tabular}

${ }^{a}$ PKC (S) - Solvent extracted palm kernel cake; PKC (E) - Expeller press palm kernel cake; PPF - palm press fibre; POME - palm oil mill effluent; OPF - oil palm fronds; Cocoa pod (D) - dried cocoa pod; Cocoa pod (F) - fresh cocoa pod; Pineapple PW - pineapple whole plant waste.

OPBP has been used in many dietary composition of livestock raised in intensive system and has also been used as supplementary feedstuff in almost all types of livestock species. The major contribution of OPBP is as feed ingredients for the ruminant animals. Higher percentage of OPBP in the diets formulation of ruminant has been evaluated in many 
research institutions and universities (Dahlan et al., 1992; Dahlan et al., 1988). Experimentation by using OPBP as a diet in feedlot feeding showed that the quality of local beef could be improved through planned feeding systems by using the right combinations of OPBP in the diet of the animals. Studies on the effect of feeding oil palm by-products (OPBP) in intensive feedlotting using Kedah-Kelantan cattle and crossbred beef cattle showed that a diet consisting of 52\% PKC, 15\% PPF and 30\% POME was one of the best formulated diets for the feedlot operation in order to produce prime carcass characteristics from local and crossbreds. The carcass produced had the highest $\%$ carcass meat and the lowest $\%$ of carcass fat. The diet also enhanced the quality of the beef through the formation of marbling, increase juiciness and tenderness in the meat of local and crossbred cattle. The meat of swamp buffaloes fed on OPBP diet showed more tender and lower cooking loss than meat from pasture-fed animal (Dahlan et al., 1988). The study showed that all ABP formulated diets produced high quality carcasses which are better than grazing animal and lower cost of production.

\section{Oil palm fronds (OPF) as a main source of fibrous feed for ruminants}

OPF is the leaf like part of oil palm tree which is produced continuously from the oil palm (Elaeis guineensis jacq.) plant. They are readily available by-product of oil palm plantations, that are cut down during harvesting of fresh fruit bunches, pruning of senescence fronds, and felled palm during re-plantation. Economic life span of oil palm: 25 - 30 years - during replanting a huge amount of OPF also generates. To get the FFB from the oil palm plant usually 2-3 OPFs were cut. Based on 2-3 OPF/FFB and 144 plant/ha, the OPF production is about 3974 fronds/ha/year and thus the total DM production of OPF is near $5484.6 \mathrm{~kg} / \mathrm{ha} /$ year. Estimated figure of OPF (dry matter) production based on 2.6 million ha of matured oil palm plantations is about 27 million tonne/year.

Chemical composition, nutrient intake and digestibility of fresh, ensiled and pelleted OPF have been evaluated for ruminant feedings by Dahlan, 1992; Dahlan, et al., 2000. They stated that OPF is a new non-conventional fibrous feed for ruminants. The nutrient content of OPF can be summarized as; the average crude protein (CP) is about $7 \%$. OPF contains a considerable amount of lignin and silica. The average CP composition $(11.0 \%)$ in the leaflets suggests its potential value for livestock feeding as it's $\mathrm{CP}$ contents is far above the critical $6.25 \% \mathrm{CP}$ level required to maintain normal intake by ruminants. OPF leaflets had a higher $\mathrm{CP}$ and crude fat content than petiole (stem of frond). Cellulose levels are usually lower than hemicellulose in both petioles and leaflets. The fibrous (CF and NDF) content and long fibre type of OPF is suitable for higher butter fat content in milk of dairy animals.

The collection, processing, preservation and utilization of oil palm frond (OPF) have the potential to be exploited for ruminant production in intensive and extensive systems. OPF can be utilized in fresh, silage or processed (pellet) form for ruminants (Dahlan, 2000b). OPF silage has been used for dairy goat and beef production. The quality of the milk and beef were comparable with other recorded results elsewhere.

PKC and OPF can be considered as important ingredients in most of total mixed ration (TMR) formulations. PKC is readily available and contain sufficient nutrient especially crude protein to meet the nutrient requirement of cattle, goat, sheep, buffaloes and deer. OPF is the source of green fiber feed for herbivores including poultry especially ostrich. Cost of ABP based TMR were affordable and feeding management for ruminant in the feedlot is practical. The technology is suitable for smallholders and large scale commercial ruminant production. Intensive production systems can be carried out by using palm kernel expeller (PKE) and oil palm frond (OPF) as total mixed ration (TMR) (Dahlan, 2013). Usage of PKE has to be maximized in the country. Supported by the government is needed through reducing the export quota of PKE to Europe and other countries. Investment in OPF feed mills are strongly needed in order to develop our new fibrous feed source since we have vast plantations that can provide fresh OPF daily (Dahlan, 2000a; Dahlan, 2000b). The cost of fresh OPF production is almost zero. The cost incurred only for processing and milling. OPF pellet can be exported to Korea and Japan as ruminant feeds (Dahlan, 2000b).

\section{Food waste, insect larvae and unfertilized egg as energy and protein alternative source for poultry production}

The most important trait in poultry production is the efficient utilization of nutrients from feedstuff as the feed cost is one of the major components of total cost of production. According to Hinrich and Steinfield (2007), feed alone contribute about $60-70 \%$ of the total cost of poultry production. There is a need to formulate rations that will fulfill all the nutrient requirements including energy and protein for growth and production. Most of organic food waste and agricultural by-products can be converted into poultry feeds. These unconventional feed materials can reduce feeding cost and at same time recycle the waste materials and reduce pollution problem. Nearly 1.5 billion tons of spoiled and uneaten food around the world throws out each year (Park, 2012). By proper processing technology these waste 
materials can be utilized efficiently. The use of agricultural by-products, food waste, insect meal, unfertilized egg and other organic materials can be considered as an alternative source of protein-energy rich poultry feed. However, the time-consuming nature of the work, low feed efficiency, nutrient imbalance, poor environmental hygiene and the difficulty of disease prevention, made feeding wet food waste to poultry unpopular (Cho et al., 2004). The result of processed wet food wastes into dehydrated food waste product show some advantages in growth performance, carcass traits and nutrient digestibility in Taiwan native chicken (Chen et al., 2007). Hussein and Dahlan (2015) using Arabian strain of village chicken under free range conditions fed with 20 to $60 \%$ dehydrated processed food waste in their feed formulations showed similar growth performance with chicken fed on commercial feed. Starter and grower feeds using $50 \%$ dehydrated food waste (DFW) as energy source in feed formulation in order to replace corn and soybean showed optimal growth performance of village chicken in pen feeding management (Nadia et al., 2016) and inclusion up to $55 \%$ of DFW and $4 \%$ bovine bone meal (as Di-calcium Phosphate) in village chicken layers diet demonstrated a satisfactory production of good quality eggs (Yusuf et al., 2016). Experiment using dehydrated food waste as energy source for poultry and common super worm (Zophobas morio) (DMW) and unfertilized egg (UFE) as a protein supplement was conducted by Nadia et al., (2016). Recent study conducted by Mohammed Farooq Abdulhameed AlQazzaz, (2019) found that low energy to protein ratio diet $(140 ; 2668.93 \mathrm{kcal} / \mathrm{kg} / 19.5 \%)$ using DFW and black soldier fly larvae (Hermetia illucens) increased hen day and hen house egg production of laying hens and replacing of corn, soybean, fish meal with DFW, larvae meal and bone waste up to $50 \%$ in the diet improved growth performance and nutrient digestibility of broiler. The composition of DFW ( $50 \%$ of the ingredient of dry matter basis) was developed into suitable poultry diets as a source of energy and replacing grains. DFW, DMW and UFE are suitable for free range poultry production and reduced feeding cost of village chicken operation (Table 2).

DFW can be used as energy source in poultry feed formulation and can replace imported grains by $100 \%$. DMW and UFE are suitable complete protein sources for poultry. By using ICIC ways we are not only reduce cost of poultry production through replacing corn and soybean as poultry feed ingredients, but also solve organic waste disposal problems.

Table 2. Nutritional value of food waste, insect larvae and unfertilized egg as feed ingredients for poultry

\begin{tabular}{llll}
\hline NUTRIENT & Dehydrated Food Waste & Dried Meal Worm (larvae) & Unfertilized Egg \\
\hline Moisture (\%) & $9.03 \pm 0.21$ & $12.19 \pm 0.26$ & $12.56 \pm 0.27$ \\
Crude Protein (\%) & $25.18 \pm 0.45$ & $46.54 \pm 0.03$ & $46.31 \pm 0.16$ \\
Crude Fat (\%) & $20.38 \pm 0.22$ & $36.40 \pm 0.92$ & $28.60 \pm 0.27$ \\
Crude Fiber (\%) & $5.34 \pm 0.18$ & $9.50 \pm 0.07$ & 0.0 \\
Ash (\%) & $6.01 \pm 0.14$ & $5.04 \pm 0.06$ & $5.96 \pm 0.64$ \\
Gross Energy (kcal/kg) & $4,500.54 \pm 1.04$ & $5,709.0 \pm 0.98$ & $5,744.9 \pm 1.20$ \\
\hline
\end{tabular}

DFW can be used as energy source in poultry feed formulation and can replace imported grains by $100 \%$. DMW and UFE are suitable complete protein sources for poultry. By using ICIC ways we are not only reduce cost of poultry production through replacing corn and soybean as poultry feed ingredients, but also solve organic waste disposal problems.

\section{Conclusion}

We strongly believe that integrated livestock-crops plantation production systems will be a sustainable type of agricultural production system in the tropics; At least in Southeast Asia Region (Malaysia, Indonesia, Thailand, Philippines, Cambodia and others). Resource evaluation and strategic planning for sustainable agriculture is strongly needed for tropical countries in order to become "Developed Nations", without neglecting organic waste issues especially agricultural by-products and food waste disposal problems. Appropriate technological innovation is needed for re-cycle and re-use these materials in order to develop efficient, clean and profitable business.

By considering these resources and opportunities; huge land bank of plantation sector, skilled human resources, ample natural resources, strategic location and tropical environment and together with these development approaches; green business and adapting green technology (3Ps-people, planet, profit) and application of marketing mix concept (4Ps products, price, place, promotion) the countries target to solve food security problems can be achieved in near future. 


\section{References}

Aliyu Ahmed Yusuf. 2016. Utilization of organic and inorganic calcium and dehydrated food waste in improving egg production and egg quality of village chicken layers. Master of Science thesis, Universiti Putra Malaysia.

Awaludin R. 2000. Guideline on cattle integration in oil palm plantation: Manual for planters. Malaysian Palm Oil Board. Min. Primary Industries, Malaysia.

Baker S. 2006. Sustainable Development. Routledge. New York.

Campbell BM, Sayer JA. Editors. 2003. Integrated Natural Resource Management: Linking productivity, the environment and development. CABI Publishing. Cambridge, MA. USA.

Chen KL, Chang HJ, Yang CK, You SH, Jenq HD, Bi Yu. 2007. Effect of Dietary Inclusion of Dehydrated Food Waste Products on Taiwan Native Chicken (Taishi No. 13). Asian-Aust. J. of Anim. Science. 20 (5):754-760.

Cho YM, Lee GW, Jang JS, Shin IS, Myung KH, Choi KS, Bae IH, Yang CJ. 2004. Effect of Feeding Dried Leftover Food and Growth and Body Composition of Broiler Chicks. Asian-Aust. J. Anim. Sci. 17:386-393.

Dahlan I. 1992. The nutritive values and utilization of oil palm leaves as a fibrous feed for goat and sheep. Proceedings of $6^{\text {th }}$ AAAP Animal Sc. Congr. Vol. III pg. 271 AHAT, Bangkok.

Dahlan Ismail. 1993. System analysis application for integrated small ruminant-tree cropping production systems. In Recent advances in methodologies. Advances in sustainable small ruminant-tree cropping integrated systems. Eds; Sivaraj, S. Agamuthu, P., Mukherjee, T.K. IDRC/CRDI. Univ. Malaya. 45-54.

Dahlan I. 2000. Integrated animal-agriculture production systems. Agro-search. 7(2); 8-14.

Dahlan I. 2000a. Oil palm frond, a feed for herbivores. Asian-Aust. J. Anim. Sci. 13:300-303.

Dahlan I. 2000b. Oil palm frond (OPF): A potential bio-waste material for commercial feed production. Agro-Search. 7(1)229-34.

Dahlan I. 2002. Sustainability of Tropical Animal-Agricultural Production Systems: Integration of Dynamic Complex Systems. UPM Publication.

Dahlan I. 2005. Deer-Acacia integrated production system: Estimation of ecological carrying capacity. In Proceedings AHAT/BSAS International Conf. Nov. 14 - 18, Khon Kaen, Thailand. "Integrating livestock-crop systems to meet the challenges of Globalisation". Vol.2:131.

Dahlan I. 2009. Integrated Production Systems. In: Management of agricultural, Forestry and Fisheries Enterprises. Vol. II. UNESCO-EOLSS. e-book. 7 p.

Dahlan I. 2009. Bioparks: Integrated production / recreational systems. In: Management of agricultural, Forestry and Fisheries Enterprises. Vol. II. UNESCO-EOLSS. e-book. 13 pages.

Dahlan I. 2013. Agricultural by-products as total mixed rations for buffaloes. In Proceedings of Buffaloes International Conference. Makassar, Indonesia. 167-184.

Dahlan I, Dawend J. 2013. Growth and reproductive performance of sambar deer in Sabal Forest Reserve of Sarawak, Malaysia. Tropical Animal Health and Production. 45:1469-1476

Dahlan Ismail, Dawend Jiwan. 2015. Browsing preference and ecological carrying capacity of sambar deer (Cervus unicolor brookei) on secondary vegetation in forest plantation. Animal Science Journal. 86, 225-237.

Dahlan I, Kamal Hisyam AW. 2014. Sustainability of cattle-crop plantations integrated production systems in Malaysia. International Journal of Development and Sustainability. 3(2): 252-260

Dahlan I, Abu Hassan O, Sukri MHI. 1988. Meat quality and muscles characteristics of feedlot and grazing swamp buffaloes. MARDI Res. J. 16(2): 133-139

Dahlan I, Rahman-Haron A, Sukri MHI. 1992. Effect of agricultural by-product diets on carcass characteristics of four types of cattle in the feedlot. Asian-Aust. J. Anim. Sc. 5:3:455-459

Dahlan I, Nik Muhamad M, Sabri M. 1994. Farming of chital, fallow and rusa deer on right-of-way land of gas pipeline. Malay. J. Anim. Sci. 1(1): 19-23. 
Dahlan I, Islam M, Rajion MA. 2000. Nutrient intake and digestibility of fresh, ensiled and pelleted oil palm frond (Eleias guyanansis) by goats. Asian-Aust. J. Anim. Sci. 13:10: 1407-1413

Dahlan I, Sukri MHI, Hassan OA. 1988. Body components and carcass characteristics of swamp buffaloes fed with oil palm by-products or grass diet. MARDI Res. J. 16(2): 125-132.

Gallopin GC, Raskin PD. 2002. Global Sustainability; Bending the curve. Routledge, London, UK.

Henrichs J, Steinfield H. 2007. Feed availability inducing structural change in poultry sector. In Poultry in the 21 st Century. http://www.fao.org/Ag/againfo/home/events/bangkok

Hussein, S., Dahlan I. 2015. Growth performance of free-range village chickens fed dehydrated processed food waste. Mal. J. Anim. Sci. 18(1): 77-86.

Jackson S, Summer JD, Leeson S. 1982. Effect of Protein and Energy on Broiler carcass Composition and Efficiency of nutrient Utilization. Poultry Science. 61:2224-2231.

Lang T, Heasman M. 2004. Food wars: The global battle for mouths, minds and markets. Earthscan. London, UK.

Mohammed Farooq Abdulhameed Al-Qazzaz. 2019. Assessment of alternative feed sources with different levels of energy to protein ratio towards enhancement of layer and broiler performance. Doctor of philosophy thesis, Universiti Putra Malaysia.

Nadia N, Dahlan I, Lokman HI, Tee TP. 2016. Effect of different energy to protein ratio in starter diet with dehydrated food waste, super worms and unfertilized eggs on growth performance of village chicken. Mal. J. Anim. Sci. 19(1): 15-22

Park A. 2012. Waste Not: Can old food really be repurposed? Times. September 10, 2012. Page 16

Spedding CRW. 1996. Agriculture and the citizen. Chapman \& Hall, London, UK.

Yusuf AA, Dahlan, I, Poy TT. 2016. Effects of different sources of dietary calcium on egg quality of village chicken layers. Journal of Agriculture and Environmental Sciences. DOI: 10.15640/jaes. 